\title{
Introduction: Aspects of Interiority
}

\author{
Andrew Douglas and
}

A.-Chr. Engels-Schwarzpaul

Impelling this edition of Interstices is the sense of an undervaluation - critically, aesthetically, professionally - of interiority. Being closest and most proximate, interiority (in its various cognate forms: inside, innerness, the interior, the domestic, the private, the intimate, etc.) lies, we argue, in a persisting shadow zone of critical scrutiny and selective professional attendance. Implicated in one of the most persistent Western cultural dichotomies (inside/outside), interior 'types' of space have long acted as flash points through which anxious concerns about the limits and identity of practice and thought in the spatial arts have been channeled. ${ }^{1}$ Not coincidently have they been assigned a minoritarian status. Cursorily put, interiority is routinely the casualty of a quarantining edict that has insistently settled it 'inside'. For our part, we have looked to unsettle this closeting effect, bringing the interior 'out', so to speak, to better sight the effects of an "interior machinery" at work in a variety of places and at a range of spatial 'scales' (Fuss 1991: 01).

Accordingly, we view interiority as in no way substantive, self-evident, or settled. Rather, we seek to catalogue its deep implication in experiences, categories and designations indicative of the outside, of publicness, and of collective force. Equally, we attend to the condensing and intensifying capacities of interiority, finding in containing space - with its appeals to, and effecting of, refuge, shelter and limitation - a political consecration, even when that communing may be as modest as a solitary confining in place.

Amongst the earliest philosophical depictions of 'modern' interiority - an emblem for all that the interior has subsequently had claimed in its name - are René Descartes' deliberations in, and on, various "stove-heated" rooms (the first somewhere in a wintery town on the Danube in 1619). ${ }^{2}$ They condense what we hope both to draw into awareness, and in key ways, exceed in this issue: namely, as Diana Fuss suggests, that not only do we inhabit interiors but that they also inhabit, habituate and orientate us (2004: 2). Descartes' private 'refuges' for philosophically rehearsing a "methodical doubt" were simple, cellular rooms, whose confines defined the thinking-self as singular, removing the confounding effects of collective, political life and accumulated thought; in short, they proselytised for time apart. ${ }^{3}$

In this they form a proto-bourgeois model portending a shift from the early modern communal house to the private domestic interior arising in the wake of the social and civic turmoil of late eighteenth-century revolutionary change (Fuss 2004: 3). The commodious, stove-heated room, as a spatial model - something that itself might be thought of as a mechanism for managing the deleterious consequences of time - has continued to inhabit the Western cultural imagination. The "topophilic" domestic poetics of Gaston Bachelard (where, according to Henri Lefèbvre (1991: 121), an "almost absolute space" of intimacy binds "Home and Ego" through well-housed memories) amount, no less than the long-venerated cabins, huts, and retreats, to figures of pause enduring over an otherwise tempestuous, outside temporal background.

Nevertheless, Descartes' stove-heated rooms bring into view something that was perhaps occluded in the subsequent nineteenth century "phantasmagoria of the

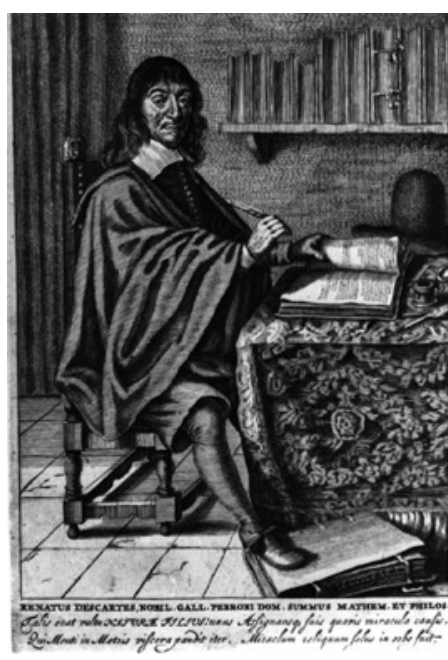

René Descartes (1596-1650) at work. (Wikimedia Commons)

1 Amongst which we include architecture, interior architecture and design, furniture design and various scenographic mediums: theatre, film, exhibition, installation and performance.

2 Descartes' biographer Adrien Baillet (1649-1706) dated the occasion 10 November, 1619 , and located it in a town near Ulm in Germany. In Discourse on the Method, Descartes described it this way: "While I was returning to the army from the coronation of the Emperor, the onset of winter detained me in quarters where, finding no conversation to divert me and fortunately having no cares or passions to trouble me, I stayed all day shut up alone in a stove-heated room, where I was completely free to converse with myself about my own thoughts." (2007a: p. 116)

3 These rooms were envisaged as literally places of pause where a demolition of received thought could occur: "So today I have expressly rid my mind of all worries and arranged for myself a clear stretch of free time. I am here quite alone, and at last I will devote myself sincerely and without reservation to the general demolition of my opinions." (2007b: p. 12) 
interior" - as Walter Benjamin characterises the centripetal, bourgeois drive to recast the dwelling as a "universe of the private individual" in compensation for "the absence of any trace of private life in the big city" (2002: 19-20). The sparsely appointed environ Descartes deemed necessary to thought in its untutored state was strikingly centrifugal. It offered a seemingly essential vantage point for deliberating over a remaking of the world, in what Antonio Negri (2007) terms an early modern "Prometheanism" inherited from a preceding humanism. If for the latter it was enough to 'encounter' and thereby reframe the world in human terms, the Modern Age desired knowledge as a means, a fulcrum, for "possessing” the world in total (37).

But how did the private room come to exemplify this Prometheanism? Negri's consideration of Descartes' use of metaphor offers a clue: firstly, Descartes' famous appeal (from the first of the stove-heated rooms recalled in Discourse on the Method) to the cleared foundation of housing built anew under the aegis of a single hand covertly borrowed from a Renaissance reworking of urban space. The simple, solitary room, like the "building undertaken and completed by a single architect" in an earlier Prometheanism, is reworked to better signal the potency of a self-authoring individual. Secondly, an aligning of science and philosophical method rests on "step by step", deductive processes favouring "self-evident", "simple natures" (Descartes 2007a: 20) suited to "analytic division and productive reconstruction” (Negri 2007: 97). For Descartes, this reconstruction was redolent of "artisan techniques" whose constructive simplicity was evident in "weaving and carpet-making" and the "more feminine arts of embroidery" (2007a: 35) - crafts indicative of an incremental making, where the whole is manifestly greater than its parts. In the context of a broader seventeenth century political transformation, their appeal to Descartes was likely due to a "class self-identification" (broadly mercantile and entrepreneurial) which borrowed from the "cosmopolitan humanism" of the earlier Italian city states (Negri 2007: 95).

For Negri, this explains the persistence of humanist metaphors in Descartes; they signal a proto-bourgeois imagination that sought a mediation between the rising Absolutist monarchical power consequent to the Thirty Years' War (1618-1648), and a disenfranchised and dispossessed multitude left to circulate outside the older vertical feudal ties of caste and land. However, with the state above and an insurrection below, this emerging class could claim rightful place neither in the court nor on the streets. Instead it proselytised for a domain of industrious action and self-making that Descartes depicted as provisionally private. In search of a 'reasonable' place for its enterprise, this emergent bourgeois class gradually made the interior both pivotal to its centrifugal concerns and routinely immune to scrutiny of its claims to 'reasonableness'. The interior so depicted was a political place, whose positing of a mediated world, however, was not recognised as such. Perhaps there is no better depiction of this critical 'provisionality' of interior place and its essential sidelining, than in the Discourse on the Method:

Now, before starting to rebuild your house, it is not enough simply to pull it down, to make provision for materials and architects (or even train yourself in architecture), and to have carefully drawn up the plans; you must also provide yourself with some other place where you can live comfortably while building is in progress. (emphasis added, 2007a: 122) 
This indefinitely situated "other place" then, a place given over to comfortable waiting, is much like a site shed, provisionally called on to see out the implementation of a project, only to be dispatched in the end. Overlooked from it is a worldmaking as the interlude to a world-possession to come.

In commencing this issue with Descartes settled in his stove-heated room, we have in mind the likelihood that such interiors were never crucibles for a muted withdrawal but, rather, a political device, a veritable contact apparatus, whose progressive ethos, spanning from the Classical to the Modern Ages, has contributed to an "interior machinery" inhabiting us still (Negri 2007: 325). Further, Negri asserts an explicate parallel between Descartes' historical situation and our own today. If bourgeois reason grappled with the excesses of aristocratic power and the risks of a "refeudalization", we find ourselves caught in a similar "crisis" in which an older State-directed capitalism faces the excesses of a new global governance and (mis) management, this time in the name of "'privatization"” (320-21). Consequently Negri parallels the emergent seventeenth-century bourgeoisie with the current "proletarian multitude". The question arising with such an isomorphism is, what allegiances, political compromises, spatial configurations and freedoms might interiority now portend? A lingering nineteenth-century misrecognition of interiority as centripetal inhabiting belies the evidence of a radical centrifugation at the heart of interiors everywhere in the wake of contemporary adventures in refeudalisation.

Contributors to this issue were asked to consider interiority in terms of unsettled containment - a thematic aiming beyond the prevailing object-cult in design and architecture, and a neglect of the interior generally. Despite an incessant bourgeois proselytising for the merits of an inside/outside partition (of workplaces and dwellings, public and private domains), we were interested in inside-outside reversals, public-private conflations and vitalising contact-intimacies and alliances that pitch up against a backdrop of stalely replicated public non-places (Augé) and an often banal, architectonic formalism.

In response, the first two contributions to this issue engage with Peter Sloterdijk's thinking in the context of Aotearoa/New Zealand. Tina Engels-Schwarzpaul, in "Restless Containers: Thinking Interior Space", draws on Sloterdijk to explicate what amounts to a complex field of containment and infinite overlappings of existential spheres. She reads this useful, if Euro-centric, perspective against the place-relations and collective enfoldings integral to Māori and Pacific cultures - a mobilisation of interiority that in many ways eludes Sloterdijk's depiction of spherical life. Also drawing on Sloterdijk's writings, Sean Sturm and Stephen Turner discuss, in "Built Pedagogy", The University of Auckland's Business School as a local manifestation of "U 2.0", or, "The Transcendental University". They show how a thoroughly market-oriented appropriation of design, in its insistent appeal to openness (atria, curves, glass), closes off other kinds of talk. As "built pedagogy", the Business School renders concrete a geo- and biopolitical frontierism transforming teaching and learning.

Looking further afield, Ross Jenner, in "Inner Poverty", draws his readers into a detailed encounter with Zumthor's Brother Klaus Field Chapel at Wachendorf, Germany. This encounter presses into a densely enacted place and material reference, which preserves and maintains, in the name of a modest poverty, making over the made and the force of matter over form. Revealed is an interior that is all externalisation, unfolding as a setting/unsettling of time. On the other hand, Deborah van der Plaat seemingly focuses her investigation solely on the interior in "Cosmopolitan Interiors”. Yet, in a reading of Oscar Wilde's lecture "The House Beautiful”, the

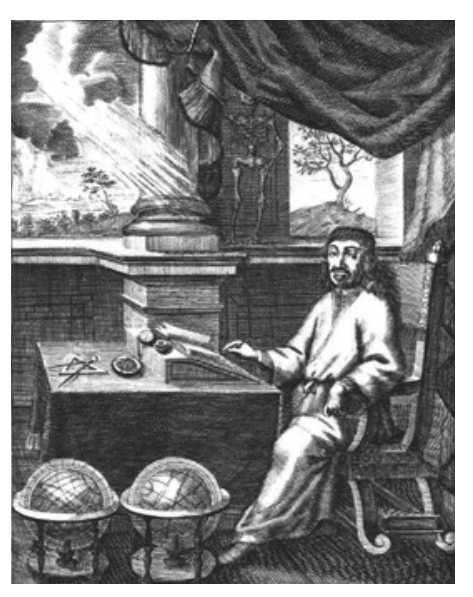

René Descartes in his study, 17 th century engraving (marilynkaydennis). 
blinds of the late nineteenth-century aestheticised interior are shown to open onto a panorama of nationalist and race politics. Wilde's lecture positions the interior no longer as the counterpart of, or retreat from, the global consciousness of Empire, but as its very condensing.

The next three contributions consider interiority across divergent media: Stefanie Sobelle explores in "Inscapes" the correlations between architectural and fictional interiors. She finds Mark Z. Danielewski's novel House of Leaves (2000) exemplarily staging a problematic in dwelling; in it no simple correspondence between inside and out can be identified, nor can a constancy of form constrain the perpetual passage-work induced by the interiority it propagates. In "Life at the Periphery", AnnMarie Brennan turns to Neorealism in cinema to consider Rome's post-war remaking by way of Kevin Lynch's exploration of "imageability" developed in a parallel American context. She intersects Lynch's charting of a complex urban, economic and societal remodelling with Gilles Deleuze's consideration of Neorealist film, particularly his identifying of disorientated any-spaces-whatever. Kate Linzey examines in "Reflective Interiors" different notions of interiority in Okamoto's Tower of the Sun and E.A.T.'s Pepsi Pavilion at the Osaka Expo '70. She argues that - contrary to appearances - the seemingly opaque Tower of the Sun is enlivened by an interior vitality while the Pepsi Pavilion's lasting influence is due not to its interior but to its exterior.

John Di Stefano and Dorita Hannah conclude the refereed section with "Intermission", in which they explore the transformative moment that occurs when the homogeneity of theatrical space and time is interrupted and broken by the uncanny presencing of an unscripted and unimaginable element. Javier Téllez' work and the 2002 Moscow theatre siege provide their frame of reference.

For this issue, we invited two papers: the first is "Disorientation and Disclosure" by David Leatherbarrow, which considers architecture as a form of spatial knowledge. Its settings - particularly interior settings - are ways of knowing one's place in the world which are not given but achieved in response to changing conditions. In the alternation between orientation and disorientation, the discovery of directionality and sense is also the disclosure of spatial understanding. Disorientation is thus the point of departure for productive design, and the interior, far from being a space of retreat or withdrawal, is nourished by external conditions it cannot control, but which qualify its spatial, historical, environmental, and cultural sense. The second invited paper, "Architecture As an Art of Immersion” by Peter Sloterdijk, was published originally in German in 2006. Sloterdijk looks at immersive configurations in politics, culture and everyday life practices as they occur and change over time and in different places. Humans do not just lie about, selfcontained like pebbles, but inhabit the world ecstatically and openly. Architecture, particularly interior architecture, designs embedded, immersive situations indicative of this fundamental human condition, in which we oscillate between "the desire to be embedded and the desire to break free".

John Walsh opens the non-refereed section with "Just Looking", an account of publishers' complicated relationships with the seen in architectural journals. Rafik Patel in "An Opening of Tanwir", look at events in Cairo in January 2011. Gerrit Confurius examines "Modernism's Secret Anxieties" in places as diverse as Kafka's attics, Corbusier's Radiant City, the New York Stock Exchange, and Winnicott's nursery. Lynda Simmons, in "Interior Darkness / Contained Shadow" draws attention to features in Pacific building traditions to the present day that run counter to a stereotype seeing brightness, lightness and mobility everywhere in New Zealand 
and Pacific architecture. Carin Wilson reviews Whare Mãori, a television series broadcasted by Māori Television in 2011 and Maurizio Sabini reviews Marco Frascari's Eleven Exercises in the Art of Architectural Drawing. Emma Morris presents a visual record of her installation "The Archive of Atmosphere: Installation as an interior architectural event”, and Ross Jenner reports on Santiago Calatrava's Law Faculty Library at the University of Zürich.

While these contributions each speak in their own way to an unsettled containment, it seems valid to assert across their breadth a prevailing strand; each, in the aspect of interiority they chart, finds the 'interior', to the extent that it persists, to be an event performed both with, and against, the deleterious effects of time. Descartes - routinely demeaned as the deployer of the mind-body split - predicated his First Philosophy (as blueprint for an ensuing revolution of bourgeois reasonableness) on a temporary hiatus engineered by a solitary room. Yet even this temporal stasis - a moment Descartes carefully coveted and carved out of the routine run of affairs - necessitated an opening or rent onto the outside: be that a window granting a plunging view of the street, or, perhaps more fundamentally, the very stove-heated room itself as an event remembered and, in turn, relayed through an emerging print capitalism. Seldom remembered of Descartes is that he was also a philosopher of wonder, and "[w]onder is the motivating force behind mobility in all its dimensions" (Irigaray 2004: 63-64). The stove-heated room then, like interiority as we would have it considered, mobilises unanticipated encounters with new species of space and thought. In this it might well be taken (as Gilles Deleuze and Felix Guattari have figured the precarious fold of shelter and exposure mandated by territory-making) as an umbrella bravely erected beneath a cosmic chaos (or "chaosmosis"). People, as they say, constantly put up

... an umbrella that shelters them and on the underside of which they draw a firmament and write their conventions and opinions. But poets, artists, make a slit in the umbrella, they tear open the firmament itself, to let in a bit of free and windy chaos and to frame in a sudden light a vision that appears through the rent ... (1994: 203)

\section{References}

Benjamin, W. (2002). The Arcades Project (H. Eiland \& K. McLaughlin, Trans.). Cambridge (Mass.): Harvard University Press.

Deleuze, G. \& Guattari, F. (1994). What is Philosophy? (H. Tomlinson \& G. Burchell, Trans.). New York: Columbia University Press.

Descartes, R. (2007a). The Philosophical Writings of Descartes, Volume 1 (J. Cottingham et al., Trans.). Cambridge (England): Cambridge University Press.

Descartes, R. (2007b). The Philosophical Writings of Descartes, Volume 2 (J. Cottingham et al., Trans.). Cambridge (England): Cambridge University Press.

Fuss, D. (1991). Inside/Out. In D. Fuss (Ed.), Inside/Out: Lesbian Theories, Gay Theories (pp. 01-10). London \& New York: Routledge.

Fuss, D. (2004). The Sense of an Interior: Four Rooms and the Writers that Shaped Them. London \& New York: Routledge.

Irigaray, L. (2004). An Ethics of Sexual Difference (C. Burke \& G. Gill, Trans.). London \& New York: Continuum.

Lefèbvre, H. (1991). The Production of Space (D. Nicholson-Smith, Trans.). Malden (England): Blackwell Publishing.

Negri, A. (2007). The Political Descartes: Reason, Ideology and the Bourgeois Project (M. Mandarini \& A. Toscano, Trans.). London \& New York: Verso.

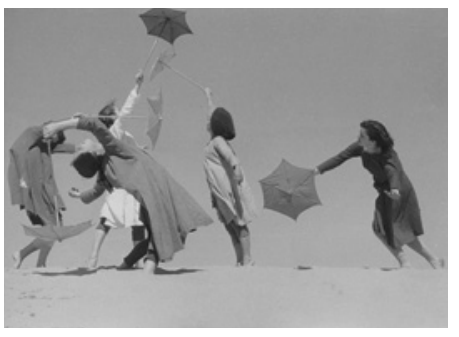

Margaret Barr's "Strange Children" [ballet], 1955 (Photographer unknown, State Library of NSW). 